\title{
Bovine and human brucellosis in the Trans-Amazonian agricultural frontier, Uruará, Pará, Brazil
}

\author{
Brucelose bovina e humana na fronteira agrícola da rodovia \\ Transamâzonica, Uruará, Pará, Brasil
}

\author{
Valéria Stacchini Ferreira Homem ${ }^{1 *}$; Marcos Bryan Heinemann ${ }^{2}$; \\ Zenaide Maria de Morais Higa ${ }^{3}$; José Soares Ferreira Neto ${ }^{4}$
}

\begin{abstract}
We evaluated the prevalence of brucellosis in cattle and humans on properties characterized as family farms in the municipality of Uruará, state of Pará, located on the border of the Trans-Amazon Highway, in a serological study. We randomly sampled cattle and humans from 67 family farms. Cattle sera were tested with buffered acidified antigen and human samples were tested using the slow tube agglutination test (titration of 80 as a cutoff point). The prevalence of bovine brucellosis was 52\% [90\% CI: 42;63]. The prevalence of households with at least one brucellosis positive individual was $21 \%$ [13;31]. In households with at least one positive test, $23 \%$ of subjects were positive (range $8 \%$ and $50 \%$ ). Five percent (21/422) of all human samples tested were positive. This high exposure rate in humans is a result of high cattle infection rates. We expect that in regions of Brazilian with a high prevalence of bovine brucellosis, there is also a high rate human exposure; however, few human cases have been reported. This is likely because of the largely non-specific symptoms of human Brucella abortus infections. Hopefully this study will bring about new information to public and animal health authorities involved in formulating policies aimed at decreasing disease prevalence.
\end{abstract}

Key words: Bovine. Brucellosis. Human. Serology. Trans-Amazonian. Uruará.

\section{Resumo}

Realizou-se estudo sorológico da prevalência da brucelose em bovinos e humanos no município de Uruará, PA, localizado às margens da rodovia Transamazônica, especificamente em propriedades caracterizadas como familiares. Foram aleatoriamente selecionadas 67 propriedades, onde foram amostrados os bovinos e os humanos integrantes dos núcleos familiares. Os soros bovinos foram testados com o antígeno acidificado tamponado e os humanos foram submetidos à soroaglutinação lenta em tubos, adotando-se como ponto de corte o título 80. A prevalência de focos de brucelose bovina foi de $52 \%$ [42; 63]. A prevalência de núcleos familiares com pelo um indivíduo positivo ao teste sorológico foi de $21 \%$ [13; 31]. Nesses núcleos familiares infectados, o percentual de indivíduos positivos variou de $8 \%$ a $50 \%$, com média de $23 \%$. Para todos os humanos examinados, a frequência de indivíduos positivos foi de 5,0\% (21/422). Essa alta exposição humana à brucelose é resultado da alta prevalência da infecção em bovinos. Assim, é razoável supor que nas regiões brasileiras onde forem verificadas altas prevalências de brucelose bovina deve-se esperar que também haja uma alta taxa de exposição da população humana rural ao agente, muito embora sejam raras as notificações de casos humanos; provavelmente, pelo caráter predominantemente inespecífico da sintomatologia da infecção humana por Brucella abortus.

Palavras-chave: Bovinos. Brucelose. Humanos. Sorologia. Transamazônica. Uruará.

\footnotetext{
Pesquisadora, Ministério da Agricultura, Pecuária e Abastecimento, MAPA, Brasília, DF, Brasil. E-mail: valeria.homem@ agricultura.gov.br

2 Prof., Faculdade de Medicina Veterinária e Zootecnia, Universidade de São Paulo, USP, São Paulo, SP, Brasil. E-mail: marcosbryan@usp.br

3 Pesquisadora, Faculdade de Medicina Veterinária e Zootecnia, USP, São Paulo, SP, Brasil. E-mail: zenaide@usp.br

4 Prof., Faculdade de Medicina Veterinária e Zootecnia, USP, São Paulo, SP, Brasil. E-mail: jsoares@vps.fmvz.usp.br

* Author for correspondence
} 


\section{Introduction}

The development of rural areas in forest ecosystems has formed the Amazonian agricultural frontier; here, the primary forest has been progressively replaced with family plantations of coffee, cocoa, black pepper, rice, cassava, beans, pastures, degraded areas, and areas of secondary vegetation. Forested areas are cleared and burnt for crop cultivation, typically by settlers from other regions in search of arable land. The agricultural frontiers extend for thousands of kilometers along the eastern, southern, and western borders of the Brazilian Amazon, and include the states of Pará, Tocantins, Maranhão, Mato Grosso, Rondônia, and Acre. These areas have family farms where husbandry techniques differ from those used in large production systems because of the smaller herd sizes and the closer relationship between humans and animals.

Over the past few years, cattle production has become an essential component of family farming; this is particularly due to the instability of annual and perennial crops, which are subject to frequent price fluctuations and difficulties in production. Therefore, many family farmers prioritize livestock production at the expense of agriculture. This trend has been designated the "cattle breeding process" ("pecuarização") and has occurred across all regions of the Eastern Amazon.

The construction of highway BR 230 (the TransAmazonian Highway) catalyzed an agricultural frontier in Pará formed by the intensive occupation of the Amazon that began in the late 1960s. The building of this highway and the implementation of integrated colonization projects by the National Institute of Colonization and Agrarian Reform (Instituto Nacional de Colonização e Reforma Agrária-INCRA) caused an intense migration of large populations and the formation of family farms along the highway and in the surrounding areas. One of the most developed areas was located at the $180 \mathrm{~km}$ mark of the Altamira-Itaituba stretch of the
Trans-Amazonian highway; this area originated the center of the Uruará municipality and is an example of the development model in the region.

Cattle breeding is crucial to the sustainability of Uruará family farms and is a source of income. Veiga et al. (1996) reported that cattle are a major investment of the small farmer, are a major source of food (particularly milk used for domestic consumption), and can generate extra income if and when they are marketed (TOURRAND et al., 1996). Approximately one-third of producers in the municipality reported abortion, which accompanied a decrease in female fertility in the early 1990s (VEIGA et al., 1996; LAU et al., 1997); this indicates the prevalence of reproductive diseases in Uruará. Lau et al. (1997) reported that the rate of seropositivity for brucellosis in cattle from a convenience sample was $12 \%$.

In the family production system, the close contact with animals is an occupational risk and can facilitate the transmission of diseases, such as brucellosis. Therefore, due of the lack of epidemiological information regarding the status of human and bovine brucellosis in northern Brazil, particularly in regions that are dedicated to family farming, we aimed to estimate the prevalence of bovine brucellosis on family farms in Uruará.

\section{Materials and Methods}

The study was designed to determine the prevalence of bovine brucellosis on family farms in Uruará (state of Pará), and had the following parameters: $\mathrm{N}=4200$ (Source: INCRA); estimated prevalence $=0.50 ;$ error $=0.10 ;$ confidence level $=$ 0.90. The calculations were made using Epi Info software version $6.02 ; 67$ properties were randomly selected for the study. All fieldwork was conducted in 1998.

Blood samples were collected from all bovines and family members of the selected properties. Human blood was collected by a nurse from the 
Municipal Health Center according to biosafety standards. A questionnaire was conducted regarding animal husbandry, sanitary practices, and disease knowledge.

Serum from processed blood samples was stored at $-20^{\circ} \mathrm{C}$ until serological tests were conducted to diagnosis brucellosis. For cattle, the rapid plate agglutination test with buffered acidified antigen was used. For owners that did not vaccinate their cattle against brucellosis, the test was performed on the entire herd; for owners that did vaccinate their cattle, the test was performed on animals older than 30 months. Animal age was estimated via dentition analysis. For humans, the slow agglutination test, which is considered the standard test for serodiagnosis of brucellosis in humans, was used (ARAJ et al., 1988; CASTAÑEDA et al., 1991; COOPER, 1992; MEYER, 1986; MOYER et al., 1987). The antigen used was specific for this test, and has been used by the Ministry of Agriculture since February of 1998. A standard protocol was used (ALTON et al., 1975). The cutoff point was a titration value of 80 , which is recommended for regions where bovine brucellosis is endemic (HOSSAIN et al., 1991; QAZILBASH; BARI,
1997). The herd was considered infected when at least one animal tested positive; the same criterion was adopted for households.

All data obtained was recorded in a database and analyzed using Epi Info software version 6.02 and SPSS.

\section{Results}

The prevalence of bovine brucellosis in Uruará was $52 \%$ [90\% CI: 42;63]. In the properties evaluated, the percentage of positive cattle varied from $3 \%(1 / 39)$ to $62 \%(16 / 26)$ with an average of $15 \%(150 / 1008)$. The frequency of positive animals in the population tested was $8.5 \%(150 / 1757)$.

The occurence of households with at least one positive individual based on the serologic test was $21 \%[13 ; 31]$. In households with at least one positive test, the percentage of positive subjects ranged from $8 \%(1 / 13)$ to $50 \%(2 / 4)$ with an average of $23 \%$ (21/92). Among their examined members the frequency of positive individuals was $5.0 \%$ (21/422), as shown in the Table 1 (Number of positive individuals, stratified by age and titration, for brucellosis in Uruará, state of Pará, during 1997).

Table 1. Number of positive individuals, stratified by age and titration, for brucellosis in Uruará, state of Pará, during 1997.

\begin{tabular}{lcccccccc}
\hline \multirow{2}{*}{ Age in years } & \multicolumn{8}{c}{ Titration } \\
\cline { 2 - 9 } & 20 & 40 & 80 & 160 & 320 & 640 & 1,280 & 2,560 \\
\hline $0-10$ & 15 & 11 & 3 & 1 & 0 & 0 & 0 & 0 \\
$11-20$ & 26 & 16 & 5 & 2 & 0 & 0 & 0 & 0 \\
$21-30$ & 13 & 8 & 1 & 2 & 0 & 0 & 0 & 0 \\
$31-40$ & 11 & 6 & 2 & 0 & 0 & 0 & 0 & 0 \\
$>40$ & 12 & 10 & 4 & 1 & 0 & 0 & 0 & 0 \\
Total & 77 & 51 & 15 & 6 & 0 & 0 & 0 & 0 \\
\hline
\end{tabular}

\section{Discussion and Conclusion}

A high prevalence of bovine brucellosis was found in Uruará during 1997; this is consistent with studies conducted Midwestern and Northern states over the subsequent decade (41\% in Mato Grosso
[95\% CI: 38; 44] (NEGREIROS et al., 2009), 42\% in Mato Grosso do Sul [95\% CI: 37; 44] (CHATE et al., 2009), 35\% in Rondônia [95\% CI: 32; 38] (VILLAR et al., 2009), 21\% in Tocantins [95\% CI: 19; 23] (OGATA et al., 2009), and 18\% in Goiás 
[95\% CI: 15; 20] (ROCHA et al., 2009). In 2016 the state of Pará will determine the epidemiological status of bovine brucellosis in all its territories. Based on previous results, a high prevalence of bovine brucellosis should be expected.

Humans of all age groups were exposed to smooth strains of Brucella (Table 1), and 6/21 positive individuals had titrations of 160 ; this indicates active brucellosis and the presence of symptoms (KIEL; KHAN, 1987; YOUNG, 1991). Individuals were probably infected via consumption of milk or dairy products (only 50\% of the households reported boiling milk), contact with aborted fetus and its annexes (approximately $54 \%$ of individuals reported contact with aborted fetuses and their annexes), or accident with the B19 vaccine (approximately $20 \%$ of households used the B19 vaccine).

Brucellosis is a classic example of a zoonosis where transmission occurs exclusively from animals to humans (PAULIN; FERREIRA NETO, 2003). However, no association was found between the rate of bovine brucellosis and the rate of seropositivity in households, indicating that humans were infected from their properties as well as neighboring properties.

The high exposure of humans to brucellosis (approximately one-fifth of infected households with approximately $25 \%$ of positive individuals in these households) is due to the high prevalence of cattle infection.

Thus, in Brazilian regions with a high prevalence of brucellosis, a high human exposure rate should also be expected. However, few human cases have been reported; this is likely due to the non-specific nature of symptoms experienced by humans infected with Brucella abortus (FRANCO et al., 2007; LAWINSKI et al., 2010).

\section{Acknowledgements}

To all producers involved in this study, and their associations and families, who made it possible.

\section{References}

ALTON, G. G.; JONES, L. M.; PIETZ, D. E. Laboratory technique in brucellosis. Genebra: World Health Organization, 1975. $163 \mathrm{p}$.

ARAJ, G. F.; LULU, A. R.; KHATEEB, M. I.; SAADAH, M. A.; SHAKIR, R. A. ELISA versus routine tests in the diagnosis of patients with systemic and neurobrucellosis. Acta Pathologica Microbiologica Immunologica Scandinavica, Copenhaguen, v. 96, n. 2, p. 171-176, 1988.

CASTAÑEDA,M.R.; SANTAROSA, C.A.; LOUZADA, A. P. Brucellose. In: VERONESI, R.; FOCACCIA, R.; DIETZE, R. Doenças infecciosas e parasitárias. 8. ed. Rio de Janeiro: Guanabara Koogan, 1991. p. 520-525.

CHATE, S. C.; DIAS, R. A.; AMAKU, M.; FERREIRA, F; MORAES, G. M.; COSTA NETO, A. A.; MONTEIRO, L. A. R. C.; LÔBO, J. R.; FIGUEIREDO, V. C. F.; GONÇALVES, V. S. P.; FERREIRA NETO, J. S. Situação epidemiológica da brucelose bovina no Estado do Mato Grosso do Sul. Arquivo Brasileiro de Medicina Veterinária e Zootecnia, Belo Horizonte, v. 61, p. 46-55, 2009. Suplemento 1.

COOPER, W. C. Prevalence of antibody to Brucella in asymptomatic well individuals in Saudi Arabia. Journal of Tropical Medicine and Hygiene, Londres, v. 95, n. 2, p. 140-142, 1992.

FRANCO, M. P.; MULDER, M.; GILMAN, R. H.; SMITS, H. L. Human brucellosis. The Lancet Infectious Disease, Londres, v. 7, n. 12, p. 775-786, 2007.

HOSSAIN, A.; BAKIR, T. F.; CHOWDHURY, M. N.; KURSTAKE, E. Seroepidemiology of enteric fever and brucellosis in a developing country. Journal of Hygiene Epidemiology Microbiology and Immunology, Praga, v. 35, n. 3, p. 325-335, 1991.

KIEL, F. W.; KHAN, M. Y. Analysis of 506 consecutive positive serologic tests for brucellosis in Saudi Arabia. Journal of Clinical Microbiology, Washington, v. 25, n. 8, p. 1384-1387, 1987.

LAU, H. D.; TOURRAND, J. F.; VEIGA, J. B.; HOMEM, V. S. F.; SIMÃO-NETO, M. Cattle health and public well being in frontier areas of the Brazilian Amazon. In: IX INTERNATIONAL CONGRESS IN ANIMAL HYGIENE PROCEEDINGS, 9., 1997, Helsinki. Proceeding... Helsinki: University of Helsinki, 1997. p. 7-8.

LAWINSKI, M. L. J.; OHARA, P. M.; ELKHOURY, M. R.; FARIA, N. C.; CAVALCANTE, K. R. L. J. Estado da arte da brucelose em humanos. Revista Pan-Amazonica de Saúde, Belém, v. 1, n. 4, p. 75-84, 2010. 
MEYER, M. E. Immune response to brucellae. In: ROSE, N. B.; FRIEDMAN, H.; FALEY, J. L. (Ed.). Manual of clinical laboratory immunology. 3. ed. Washington: American Society of Microbiology, 1986. p. 385-387.

MOYER, N. P.; EVINS, G. M.; PIGOTT, N. E.; HUDSON, J. D.; FARSHY, C. E.; FEELEY, J. C.; HAUSLER JÚNIOR, W. J. Comparison of serologic screening tests for brucellosis. Journal of Clinical Microbiology, Washington, v. 25, n. 10, p. 1969-1972, 1987.

NEGREIROS, R. L.; DIAS, R. A.; FERREIRA, F.; FERREIRA NETO, J. S.; GONÇALVES, V. S. P.; SILVA, M. C. P.; FIGUEIREDO, V. C. F.; LÔBO, J. R.; FREITAS, J.; AMAKU, M. Situação epidemiológica da brucelose bovina no Estado do Mato Grosso. Arquivo Brasileiro de Medicina Veterinária e Zootecnia, Belo Horizonte, v. 61, p. 56-65, 2009. Suplemento 1.

OGATA, R. A.; GONÇALVES, V. S. P.; FIGUEIREDO, V. C. F.; LÔBO, J. R.; RODRIGUES, A. L.; AMAKU, M.; FERREIRA, F.; FERREIRA NETO, J. S.; DIAS, R. A. Situação epidemiológica da brucelose bovina no Estado do Tocantins. Arquivo Brasileiro de Medicina Veterinária e Zootecnia, Belo Horizonte, v. 61, p. 126134, 2009. Suplemento 1.

PAULIN, F. P.; FERREIRA NETO, J. S. O combate à brucelose bovina. Situação brasileira. Jaboticabal: Fundação de Estudos e Pesquisas em Agronomia, Medicina Veterinária e Zootecnia, 2003. 154 p.

QAZILBASH, A. A.; BARI, A. Sero-diagnosis of human brucellosis among TB suspect patients. JPMA Journal of Pakistan Medical Association, Karachi, v. 47, n. 10, p. 243-246, 1997.
ROCHA, W. V.; GONÇALVES, V. S. P.; COELHO, C. G. N. F. L.; BRITO, W. M. E. D.; DIAS, R. A.; DELPHINO, M. K. V. C.; FERREIRA, F.; AMAKU, M.; FERREIRA NETO, J. S.; FIGUEIREDO, V. C. F.; LÔBO, J. R.; BRITO, L. A. B. Situação epidemiológica da brucelose bovina no Estado de Goiás. Arquivo Brasileiro de Medicina Veterinária e Zootecnia, Belo Horizonte, v. 61, p. 27-34, 2009. Suplemento 1.

TOURRAND, J. F.; VEIGA, J. B.; SIMAO-NETO, M.; VALE, W. G.; FERREIRA, L. A.; LUDOVINO, R. R.; MARES-GUIA, A. P. O. Animal husbandry in agricultural frontiers of Brazilian Amazon: sustainable system or ecologic disaster. Animal Research and Development (Institut for Scientific Cooperation, Germany), Tübingen, v. 43-44, n. 1, p. 80-91, 1996.

VEIGA, J. B.; TOURRAND, J. F.; QUANZ, D. $A$ pecuária na agricultura familiar da Amazônia. O caso do município de Uruará, PA, na região da Transamazônica. Belém: EMBRAPA CPATU, 1996. 61 p. (Documentos, 87).

VILLAR, K. S.; AMAKU, M.; DIAS, R. A.; FERREIRA NETO, J. S.; BENITEZ, F.; GONÇALVES, V. S. P.; FIGUEIREDO, V. C. F.; LÔBO, J. R.; FERREIRA, F. Situação epidemiológica da brucelose bovina no Estado de Rondônia. Arquivo Brasileiro de Medicina Veterinária e Zootecnia, Belo Horizonte, v. 61, p. 85-92, 2009. Suplemento 1.

YOUNG, E. J. Serologic diagnosis of human brucellosis: analysis of 214 cases by agglutination tests and review of the literature. Reviews of Infectious Diseases, Arlington, v. 13, n. 3, p. 359-372, 1991. 
